\title{
Effect of Placental Peptide Hormones (hGG, hGS) on the Adenyl Cyclase-Cyclic AMP-protein Kinase System in Their Target Organs
}

\author{
Yuzo OHGA \\ Department of Obstetrics and Gynecology Kobe University School of Medicine Kobe, Japan \\ (Director : Professor Shimpei Tojo) \\ Department of Biorhemistry Kobe University School of Medicine \\ (Director : Professor Yasutomi Nishizuka)
}

The effects of placental peptide hormones (hCS, human chorionic somatomammotropin, and hCG, human chorionic gonadotropin) on the adenyl cyclase-cyclic AMPprotein kinase system in their target organs were studied.

The extraction method of cyclic AMP was also evaluated. The cyclic AMP level measured by Gilman's method using rat liver cyclic AMP binding protein was affected by the extraction method of cyclic AMP from the tissue and the volume of the starting material. When there was enough material, Dowex $50, \mathrm{H}^{+}$form column chromatography was effective for the extraction of cyclic AMP from tissue. But when there was only $50 \mathrm{mg}$ of material or less, it was necessary that cyclic AMP be extracted from tissue by $6 \%$ trichroloacetic acid only many samples were assayed in order to reduce error.

On the cyclic AMP binding assay itself, it was necessary to fix the time between the end of the reaction and filtering with millipore filter.

The lipolytic action of hCS was studied in rat epididymal fat pads. The level of cyclic AMP was elevated in rat epididymal fat pads in vitro and in vivo by hCS. The protein kinase activity was also increased in rat epididymal fat pads in vitro experiment by hCS. Furthermore, hCS caused an increase in the FFA level in the incubation medium in vitro and in the serum.

These results indicated that hCS acted in the lipolysis in the rat via the adenyl cyclase-cyclic AMP-protein kinase system.

The effect of hCG on the protein kinase activity in rat ovary was studied.

The protein kinase activity was increased in the ovary of normal cycle rats, pregnant rats, and premature rats in vitro by hCG. This result suggested that the effect of hCG on the rat ovary was accomplished via the adenyl cyclase-cyclic AMP-protein kinase system.

(See pp. 1310 1322) 


\title{
胎盤ペプチドホルモン（hCG, hCS）の標的細胞における protein kinase, cyclic AMP 系に対する作用
}

\author{
神戸大学医学部産科婦人科学教室（主任：東條伸平教授） \\ 神戸大学医学部第 2 生化学教室 (主任 : 西塚泰美教授)
}

大学院学生大賀 祐 造

（昭和49年 6 月17日受付）

胎盤ペプチドホルモン，特に hCS 及び hGG の標的細胞における作用機構を adenyl cyclase-cyclic AMP 系から検討した。 その結果, hCS はラット副殬脂において in vivo でも in vitro でも adenyl cyclase-cyclic AMP 系を介して脂質分解作用を持つと思われる成績を得た。

また正常性周期ラット卵巣, 妊娠ラット卵巣, 未成熟ラット卵巣のいずれの卵巣組織中 protein kinase も, hGG によって活性化された。

\section{I. 緒言}

人胎盤で hCG (human chorionic gonadotropin), hCFSH (human chorionic follicle stimulating hormone), hCT (human chorionic thyrotropin) あるいは hCS (human chorionic somatomammotropin) が産生されるてとはすでに確認されているが，てれらポリペプチドホルモンの作用機序ならびに生物学的意 義はよく知られていない.

最近 Sutherland ら ${ }^{1)}$ とつて発見された cyclic AMP が，ある種のホルモンの細胞内 mediator として 働いていることが知られ，乙の cyclic AMP は cyclic AMP dependent protein kinase に作用して，そ れを活性化するてとが，Walsh ら゙よつて明らかにされた。つまり，ホルモンの細胞内作用機構は，ホル モンによつて細胞膜に結合した酵素である adenyl cyclase が活性化され, 細胞内 cyclic AMP 濃度が増加 し，それにひきつづいて cyclic AMP dependent protein kinase (protein kinase) が活性化されるという 機序が明確となつた。

ところで，教室の村田 ${ }^{3)}$ は試験管内の実験で hCS が脂肪組織中ホルモン感性リパーゼ (HSL) の活性を たかめることを報告したが，この HSL も protein kinase によつて活性化されるととがほぼ明らかとな $り^{4)}$ ， hCS の脂質分解作用が adenyl cyclase-cyclic AMP 系を介して行なわれている可能性が強くなつて きた。

一方，hGG に関しては，既に東條 ${ }^{5)}$ とつて詳細に報告され，その後特に biological な面から足高ら ${ }^{6)}$ は妊娠初期䋘毛より精製した hGG に FSH like activity と LH like activity があることを報告した。 hGG の生化学的性格については, Bahl $ら^{7) 8) 9}$, Canfield $ら^{10)}$ の研究があり, その作用機序に関しても, 最 近では Dorrington ら ${ }^{11)}$ が試験管内の実験で, hCG が偽妊娠鬼卵巣間質組織の adenyl cyclase 活性を増加 させたと報告している。

従つて hGG も adenyl cyclase-cyclic AMP 系を介して作用を発現していると考它られるが, protein kinase が hGG によつて活性化されるか否かはまだ直接に示されていない.

そてで著者は, hCS 及び hCG と adenyl cyclase-cyclic AMP 系との関係を検討するにあたつて，まず 実験の基礎となる cyclic AMP の定䁪方法について若干の検討を加え，次いで hCS の脂質分解作用と 
adenyl cyclase-cyclic AMP 系との関係をラット副梓脂を用いた in vitro ならびそ in vivo の実験で,ま た hGG と卵巣内 protein kinase の関係を種々の生理状態下におけるラット卵巣を用いた in vitro の実 験でそれぞれ検討した。

\section{II. 実験材料および実験方法}

\section{A. 実験材料}

\section{1. 実験動物}

実験動物として日本クレア株式会社（大阪）から購入した Sprague Dawley（S.D.）系ラットを用い，一 定期間，恒温室内でオリエンタル固型飼料で飼育したのち用いた。

$\mathrm{hCS}$ の脂質分解作用の検討には, S.D. 系雄ラット, 生後 5 週（体重約 $150 \mathrm{~g}$ 前後）のものを一夜絶食さ せ，翌朝実験に併した。

hGG, FSH および LH の卵巣内 protein kinase 活性化に関する作用の検討には, 各種の生理状態下で の S.D. 系雌ラットを用いた。性周期は腟スメアで確認し, また妊娠日数は臸内に精子の存在するととを確 認した日を $\mathrm{L}_{0}$ とし, 以後 $\mathrm{L}_{1}, \mathrm{~L}_{2}, \cdots と し た 。$ 生後 14 日および21日の未成熟ラットは, 日本クレア株式会社 より購入した日に実験供した。

\section{2. ホルモン}

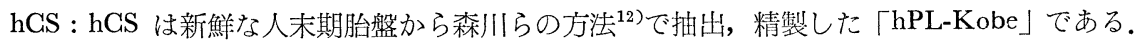

hCG : hCG は妊婦尿中より足高の方法 ${ }^{6}$ そよつて抽出，精製した sperific activity $15000 I U$ のものであ る.

FSH, LH : FSH (NIH-FSH-S4), LH (NIH-LH-S12) は the Endocrinology Study Section of the National Institute of Healtn (NIAMDD) から提供されたものである.

\section{3. その他の試薬}

$\gamma$-P ${ }^{32}$-ATP : Glynn らの方法 ${ }^{13}$ ) で標識した比活性の高い $\gamma$-P P $^{32}$-ATP（神戸大学医学部第 2 生化学教室から 提供) である.

$\mathrm{H}^{3}$-cyclic AMP : $\mathrm{H}^{3}$-cylic AMP (16〜20 $\left.\mathrm{Ci} / \mathrm{mM}\right)$ は日本アイソトープ協会から購入したものである. その他の試藻類は，半井化学株式会社（京都）の特級品を用いた。

\section{B. 実験方法}

\section{1. cyclic AMP 定量法}

cyclic AMP の定量は山村らの方法 ${ }^{14)}$ で精製したラット肝臓 cyclic AMP dependent protein kinase の 分画を適当に濃縮し，乙れを cyclic AMP binding protein として用い，Gilman の方法 ${ }^{15}$ 亿準じて binding assay を行なつた。つまり，反応液は全量 $0.10 \mathrm{ml} よ り な り ， 0.5 \mathrm{M}$ acetate buffer $(\mathrm{pH} 4.2) 0.02 \mathrm{ml}$, $10^{-7} \mathrm{M} \mathrm{H}^{3}$-cyclic AMP (16〜20 Ci $\left./ \mathrm{mM}\right) 0.01 \mathrm{ml}$ 亿 sample, $\mathrm{H}_{2} \mathrm{O}$, binding protein を含んでいる. binding protein を加えることによつて反応を開始する。 binding protein の量は使用した $\mathrm{H}^{3}$-cyclic AMP の radioactivity（約 $20000 \mathrm{cpm}$ ) の約40\% (約 $8000 \mathrm{cpm}$ ) を結合する量である。 $0{ }^{\circ} \mathrm{C} て ゙ 60$ 分間 incubation し たのち氷泠した約 $2 \mathrm{ml} の 10 \mathrm{mM}$ Tris-Gl （pH 8.0)-40mM $\mathrm{MgCl}_{2}$ 溶液を加光, 直ちに millipore filter (Type HAWP) で吸引濾過する. 同じ溶液約 $3 \mathrm{ml}$ ずつを用いて 5 回洗浄したのち, filter $5 \mathrm{ml} の$ Bray 液を入れたカウンティングバイアル中に投入し， millipore filter を完全に溶解したのち，液体シンチレー ションカウンター (Packard Tri-Garb liquid scintillation spectrometer, Model 3320) で radioactivityを 測定した。毎回 sample の代りに既知濃度の cyclic AMP を加えて Gilman の方法 ${ }^{15}$ 亿従つて standard curve を作成し, sample 中の cyclic AMP 濃度を算定した。

\section{2. protein kinase 測定}

protein kinase の測定は山村らの方法 ${ }^{14)}$ に従つて行つた。 反応液の組成は $20 \mathrm{mM}$ Tris-Cl $(\mathrm{pH} 7.5)$, $4 \mathrm{mM} \mathrm{Mg}$ acetate, $400 \mu \mathrm{g}$ calf thymus histone, $4 \mu \mathrm{M}$ cyclic AMP, $10 \mu \mathrm{M} \gamma-\mathrm{P}^{32}$-ATP, 適当量の䤉素液汃 
らなり，全量 $0.25 \mathrm{ml}$ である。酻素液を加えるととによつて反応を開始し， $30^{\circ} \mathrm{C} 10$ 分間 incubation したの ち，10\% TCA 約 $5 \mathrm{ml}$ を加光て反応を停止する。溶液をグラスフィルター (Whatman glass fiber paper GF 83) で吸引滤過し，反応試験管およびグラスフィルターを約 $3 \mathrm{ml} の 10 \% \mathrm{TCA}$ を用いて 5 回洗浄し たのち，グラスフィルターを $5 \mathrm{ml}$ の Bray 氏シンチレーター中に投入し，グラスフィルターに附着した $\mathrm{P}^{32}$ の放射能をシンチレーションカウンターで測定した。 ヒストンを除いて同一操作を行なつた時のグラスフィ ルターに残存する radioactivity は約 50〜60 cpm であつた。測定值として, cyclic AMP 存在下にヒスト ンにとり込まれた $\mathrm{P}^{32} の$ radioactivity に対する cyclic AMP 非存在下の radioactivity を百分率で表示し た. なお assay は全て duplicate assay で行ない測定值はその平均值で表示した.

\section{3. hCS のラット副䔂脂における脂質分解機序に関する検討}

i. in vitro 実験

S.D. 系雄ラットの副輧脂は断頭屠殺後採取し，小片に分切後部位による相異を避けるために at random 分けた。 incubation 用チューブはプラスティック製のものを用いた。

a. cyclic AMP の抽出

$2 \%$ bovine serum albumin を含吉 Krebs-Ringer bicorbonate buffer, pH 7.4 (2\% BSA-KRB buffer)

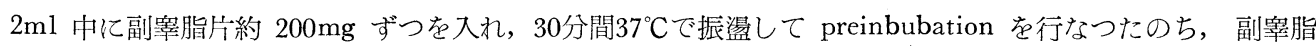
片を取り出し，口紙で水分を除去し，乙れを所定量のホルモン，薬剤を含む同じ buffer の入つたチユーブ

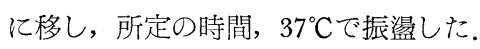

ineubation 終了後溶液中から副辠脂片をとりだし, 直ちに組織内 cyclic AMP 濃度の測定を行なつた。

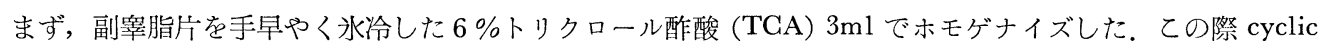
AMP の抽出操作での回収量を正確に知るために 2pmoles の $\mathrm{H}^{3}$-cycllc AMP (約 4000cpm) を TCA 中 に加えた．ホモゲネートを20分間，3000 rpm で遠沈後，中層の透明な層を別の試験管に移し， 2 倍量の工 チルエーテルを加えて振蕰し, エーテル層に TCA を抽出, 除去した。 この操作を 6 回くり返したのち, 残存エーテルを $60^{\circ} \mathrm{C}$ の温浴中で蒸発除去し, 残液を $2 \mathrm{M}$ Tris を用いて $\mathrm{pH} 7.5$ 亿調整した。 この溶液から cyclic AMP をさらに分離精製するために，Dowex $50, \mathrm{H}^{+}$型カラム $(8 \times 70 \mathrm{~mm})$ でクロマトグラフィ 一を行ない，水で溶出し， $\mathrm{H}^{3}$-cyclic AMP の放射能のあるとてろを cyclic AMP 分画として採取した. 溶液を蒸発乾固後, $0.3 \mathrm{ml}$ の水で溶解して, cyclic AMP の定量を行なつた。本操作における cyclic AMP の回収率は約 $60 \%$ であつた。

b. protein kinase assay の酩素液の調整

活性型 protein kinase は Corbin ${ }^{16) 17)}$ によつて 考案された方法で酵素液を調製して測定した。Fig. 1 はその概略である。

つまり, 副等脂を既述のように細切等分し，その 約150mgづつを用いた。 preincubation には, $1 \mathrm{ml}$ の $\mathrm{pH} 7.4$ Krebs-Ringer phosphate buffer $-0.1 \%$ BSA 溶液 ( $0.1 \%$ BSA-KRP buffer) を用い， $37^{\circ} \mathrm{C}$ で30分間行なつた. preincubation 後脂肪片を hCS $100 \mu \mathrm{g} / \mathrm{ml}$ を含む新鮮な同じ buffer 中に移し，さ らに $37^{\circ} \mathrm{C} 10$ 分間および20分間の incubation を行な つた。刘照は hCS を含まない buffer 中で incubation した. incubation 終了後直ちに脂肪片を氷冷 した $2 \mathrm{ml} の 10 \mathrm{mM}$ potassium phosphate buffer, $\mathrm{pH}$ 6.4, 10mM EDTA, pH 6.4, 5mM neophylline, $0.5 \mathrm{M} \mathrm{NaCl}$ を含む溶液で teflon-glass homogenizer

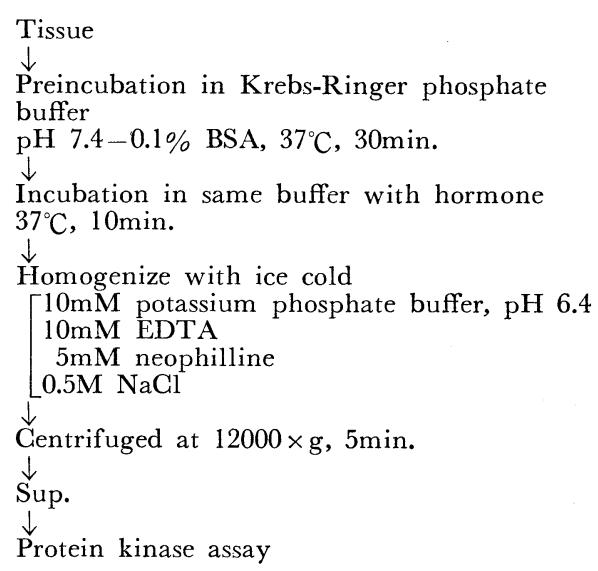

Fig. 1. Experimental procedure for protein kinase assay. 
を用いてホモゲナイズし， $12,000 \times \mathrm{g} ， 4{ }^{\circ} \mathrm{C}$ で 5 分間遠沈した．沈渣と脂肪層の中間の屏を醳素液として protein kinase $の$ asiay に供した.

protein kinase 測定と併行して, incubation 終了後溶液中の FFA は Itaya-Ui の変法 ${ }^{18)}$ で定量した.

ii. in vivo 実験

一夜絶食させた S.D. 系雄ラット腹腔内に，0.1\% BSA で溶解した hCS を体重 $100 \mathrm{~g}$ あたり $100 \mu \mathrm{g} の$ 割合で,また対照のラットには $0.1 \%$ BSA のみを投与し, 所定の時間後に断頭, 屠殺した.

断頭時に採血し, 血清中の FFA 量を Dole の方法 ${ }^{19}$ で測定した。

屠殺後手早やく切除した副窣脂のうち, 約 $200 \mathrm{mg}$ を小試験管に入れ, 直ちにドライアイスーアセトン槽で 凍結したのち, 重量を正確に科量し, 以後試験管内の実験と同様の操作で副辠脂から cyclic AMP を抽出, 定量した.

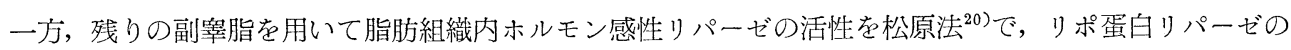
活性を中田法 ${ }^{21)}$ で夫々測定した。両りパーゼの活性は組織 $1 \mathrm{~g}$ あたり60分間に放出される FFA 量 $100 \mu \mathrm{eq} / l$ を 1 単位として表示した。

\section{4. hGG の卵巣における protein kinase 活性化に対する作用の検討}

i. in vitro 実験

実験動物の項に既述したラットのうち, 妊娠ラット以外は断頭によつて卵巣を切除した. 妊娠ラットは, フェノバルビタール剤による麻酔下に開腹し, 卵巣を切除した。

a 。卵巣内 cyclic AMP 濃度の測定

正常性周期を持つラット卵巣を手早やく切除後, 直ちに小試験管内に入れ, ドライアイスーアセトン槽中 で涷結し，科量した。科量後 2pmoles の $\mathrm{H}^{3}$-cyclic AMP (約 4000 cpm) を添加した $2 \mathrm{ml}$ の 6\% TCA で ホモゲナイズし，ホモゲネートを20分間 4000rpm で遠沈した。 上清中の TCA を 2 倍量エチルエーテル で 6 回抽出除去したのち, 残存エーテルを $60^{\circ} \mathrm{C}$ 温浴中で蒸発除去した。残液を $2 \mathrm{M}$ Tris で $\mathrm{pH} 7.5$ 亿調 整後, 凍結乾燥し, 残渣を $0.3 \mathrm{ml}$ の水で溶解して cyclic AMP 測定に供した. 本操作での cyclic AMP の 回収率は約80〜90\%であつた。

b. protein kinase assay の酵素液の調製

まず両側卵巣を $2 \mathrm{ml} 0.1 \%$ BSA-KRP buffer で $37^{\circ} \mathrm{C} 30$ 分間 preincubationしたのち, 一側卵巣は対照 としてホルモンを含まない新鮮な同一 buffer 中に移し，他側卵巣は夫々 hGG $(1001 \mathrm{U} / \mathrm{ml})$, FSH $(20 \mu \mathrm{g} /$ $\mathrm{ml})$ あるいは $\mathrm{LH}(20 \mu \mathrm{g} / \mathrm{ml})$ を含む新鮮な同一 buffer 中に移し，さらに $37^{\circ} \mathrm{C} 10$ 分間の incubation を行 なつた。 incubation 終了後卵巣を直ちに副辡脂の実験と同一の氷泠した溶液を用いてホモゲナイズし， $12,000 \times \mathrm{g} 5$ 分間 $4{ }^{\circ} \mathrm{C}$ で遠沈し，上清を醉素液として protein kinase assay に供した。

\section{III. 実 験 成 績}

\section{A. 組織内 cyclic AMP 濃度の測定に関する基礎的検討成績}

組織内 cyclic AMP 濃度を測定するにあたり, 以下の項目について基礎的条件の検討を行なつた。

\section{1. 組織から cyclic AMP を抽出する至適条件について}

ホルモンの影響により組織内 cyclic AMP の濃度は急速に変動すると思われるので22，その抽出の至適 条件を以下のでとき方法で検討した。組織はラット肝臟（約 $1 \mathrm{~g} ）$ を用い，その切除はできるだけ短時間内 に行ない，組織を小試験管内でドライアイスーアセトン槽に浸して東結した。科量後，てれを承冷した 6\% TCA (約 6ml/g) で teflon-glass homogenizer を用いてホモゲナイズし, 3000rpm 20分間遠沈して上清を 採取するが, cyclic AMP の回収量を知るためにホモゲナイズ前に $\mathrm{H}^{3}$-cyclic AMP (5pmoles, 10000cpm) を添加しておく，ての上清に 2 倍量のエチールエーテルを加えて振盪し，エーテル層を除去する操作を 6 回 くり返して上清中の TCA を除去した。残存するエーテルは $60^{\circ} \mathrm{C}$ の温浴中で蒸発させ, 残つた溶液を $2 \mathrm{M}$ Tris で pH 7.5 亿調整し, 水で全量を $6 \mathrm{ml}$ とした。 そのうち $1 \mathrm{ml}$ は直ちに Vapour Mix (Rikakikai Co., 
Ltd., Tokyo) を用いて蒝発乾固し (Exp. I), $2 \mathrm{ml}$ は Dowex 50, H+ 型カラム $(8 \times 70 \mathrm{~mm})$ でクロマト グラフィーを行ない，水で溶出されてきた $\mathrm{H}^{3}$-cyclic AMP の radioactivity のある部分を集めて蒸発乾固 した (Exp. II). 残りの $3 \mathrm{ml}$ に Walton の方法 ${ }^{23}$ にしたがつて $\mathrm{ZnSO}_{4}-\mathrm{Ba}(\mathrm{OH})_{2}$ 処理を行ない, 遠沈し

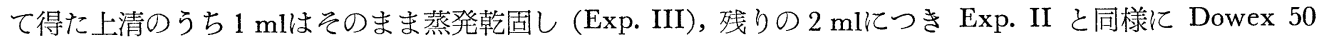

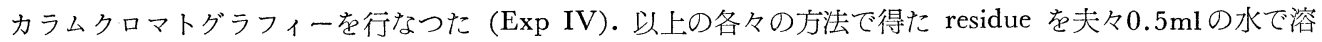
解し，そのうち0.1mIの radioactivity を測定して cyclic AMP の回収量を計算し， binding assay による 測定值を補正した. Table 1 はこの sample を用いて binding assay を行なつて得た結果である。

Table 1. Variation of cyclic AMP concentration caused by the different extraction procedure from tissue.

\begin{tabular}{c|c|c|c|c}
\hline \multirow{2}{*}{ Exp. } & \multicolumn{3}{|c|}{ Treatment } & $\begin{array}{c}\text { Cyclic AMP Concentration } \\
\text { pmoles/mg liver }\end{array}$ \\
\cline { 2 - 5 } & $6 \%$ TGA & $\mathrm{ZnSO}_{4}-\mathrm{Ba}(\mathrm{OH})_{2}$ & Dowex 50 & $2.10 \pm 0.42$ \\
\hline \multirow{2}{*}{ I } & + & - & - & $1.13 \pm 0.03$ \\
II & + & - & + & $1.95 \pm 0.51$ \\
III & + & + & - & $1.04 \pm 0.25$ \\
IV & + & + & + & \\
\hline
\end{tabular}

The values are the mean \pm S.D. $(n=6)$.

TCA 処理のみ，および TCA と $\left.\mathrm{ZnSO}_{4}-\mathrm{Ba} \mathrm{OH}\right)_{2}$ 処理を行なつた群では，測定值は従来いわれている 肝臓の cyclic AMP 濃度より大であり，バラッキも大きい. TGA, $\mathrm{ZnSO}_{4}-\mathrm{Ba}(\mathrm{OH})_{2}$ 処理に加えて Dowex 50 カラムクロマトグラフィ一処理をした群と, TCA, Dowex 50 カラムクロマトグラフィー処理をした群 ではいずれも測定值は従来の測定值と一致しバラツキも少なかつた。

\section{2. cyclic AMP 測定に必要な組織量について}

binding assay によつて組織内 cyclic AMP 濃度を測定する際に必要な最低組織量を知るために，ラット 肝臓を用いて, TGA のみによる抽出法と, TCA, Dowex 50 カラムクロマトグラフィーによる抽出法につ いて検討した. 結果を Table 2 に示す.

Table 2. Variation of cyclic AMP concentration caused by the weight of starting material.

\begin{tabular}{|c|c|c|c|c|}
\hline \multirow{2}{*}{ Treatment } & \multicolumn{4}{|c|}{ Sample weight } \\
\hline & $\leqq 30 \mathrm{mg}$ & $35 \sim 50 \mathrm{mg}$ & $80 \sim 90 \mathrm{mg}$ & $300 \sim 400 \mathrm{mg}$ \\
\hline $6 \%$ TCA & $1.44 \pm 0.67$ & $1.46 \pm 0.50$ & $1.47 \pm 0.59$ & $2.22 \pm 0.33$ \\
\hline $6 \%$ TCA + Dowex 50 & N.D. & $1.47 \pm 0.55$ & $1.03 \pm 0.28$ & $1.09 \pm 0.17$ \\
\hline
\end{tabular}

The values are the mean \pm S.D. $(n=6)$

N.D. is non detectable.

組織量が 80mg 以上ある場合には，Dowex 50 カラムクロマトグラフィーを行なつたものの測定值は従来 のものと一致し，バラツキが少ない. 組織量が30mg 以下となると, Dowex 50 カラムクロマトグラフィー を行なつたものでは, binding assay による測定が不可能となつた。

3. cyclic AMP の binding assay について

i. $\mathrm{H}^{3}$-cyclic AMP の比活性

比活性が 4.4Ci $/ \mathrm{mM}$ と 16〜20Gi/mM の $\mathrm{H}^{3}$-cyclic AMP を用いて standard curve を作成し, 両者の 第50巻 第 9 号 
優劣を検討した. Fig. 2 はその成績を示す.

比活性の高い $\mathrm{H}^{3}$-cyclic AMP を用いると,より低い浱度の cyclic AMP が測定可能であつた。

ii. cyclic AMP と binding protein の結合に対する反応時間, 温度わよび theophylline の影響 incubation の温度を $0^{\circ} \mathrm{C} と 30^{\circ} \mathrm{C}$ とし, 夫々に $6 \mathrm{mM}$ theophylline を添加したものとしないもので time course をとつて binding assay そ対する温度及び theophylline の影響を検討した. Fig. 3 はその結果で ある.

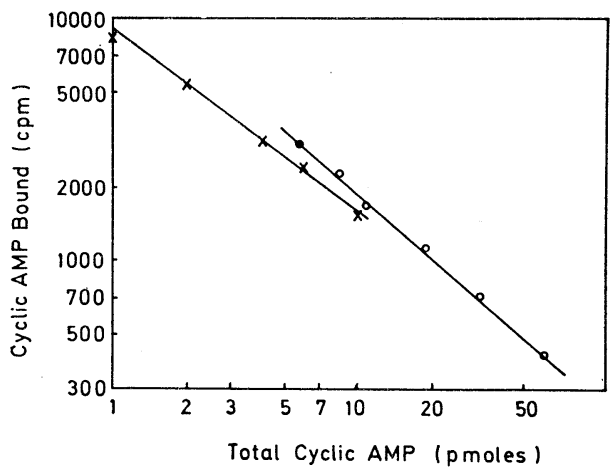

Fig. 2. Standard curve for Cyclic AMP assay.

- $\mathrm{O}$ - is the standard curve for cyclic AMP assay with ${ }^{3} \mathrm{H}$-cyclic AMP (4.4Ci/mM).

$-x-$ is the standard curve for cyclic AMP assay with ${ }^{3} \mathrm{H}$-cyclic AMP (16 20Gi/mM).

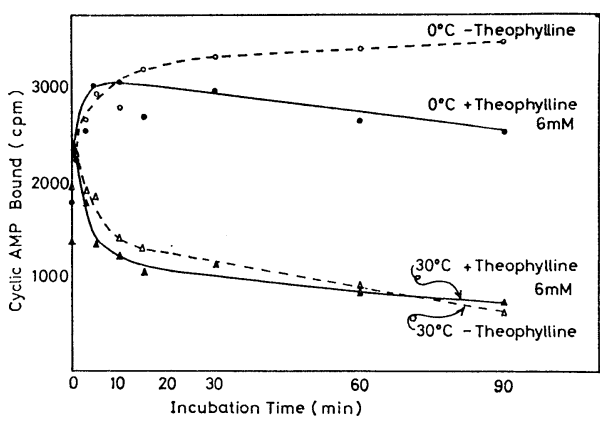

Fig. 3. Effect of incubation time, temperature and theophylline on cyclic AMP binding to binding protein.

$30^{\circ} \mathrm{C}$ では theophylline の存否にかかわらず, incubation 開始後 3 分で cyclic AMP の binding

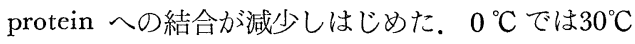
に比べて, cyclic AMP の binding protein への 結合は良好であつたが，5分以後では theophylline

を加えたもので binding protein と結合した cyclic AMP の量が漸減しはじめた。一方， $0{ }^{\circ} \mathrm{C} て ゙$ theophylline を添加しなかつたものでは incubation 5 分までは binding protein に結合した cyclic AMP 量は 急速に増加し，以後90分まで漸増したが，30分から90分までの増加はでく少なく，ほぼプラトーであつた。

\section{B. hCS のラット副睪脂における脂質分解機序に}

\section{関する検討成績}

\section{1. in vitro 実験}

$2 \%$ BSA-KRS buffer 中で30分間 preincubation したラット副鋅脂を hCS $(50 \mu \mathrm{g} / \mathrm{ml})$, caffeine (1 $\mathrm{mM}), \mathrm{hCS}+$ caffeine を夫々含む incubation 溶液 に移して，5分および15分間 incubation したのち 脂肪組織中の cyclic AMP 濃度を測定した. Fig. 4 は preincubation 直後の脂肪組織中 cyclic AMP 濃度 $(0.23 \mathrm{pmoles} / \mathrm{mg}$ wet weight) に対して, incubation 後の組織中 cyclic AMP 濃度の增減を 百分率で表示したものである.

対照および incubation 溶液に caffeine のみを 添加したものでは，脂肪組織中 cyclic AMP の濃 度は 5 分および15分間でほとんど変化しなかつた。

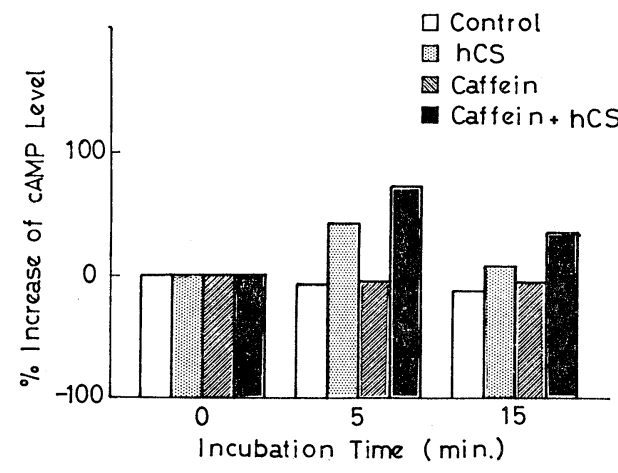

Fig. 4. Effect of hCS on cyclic AMP levels in rat epididymal fat pad in vitro. The values are the mean of 3 samples. 
$50 \mu \mathrm{g} / \mathrm{ml}$ の hCS を添加したものでは, incubation 5 分後で脂肪組織中 cyclic AMP 濃度は35\%増加し, 15分後には減少しはじめた。 hCS を $1 \mathrm{mM}$ caffeine と共に添加すると, 脂肪組織中 cyclic AMP 濃度は 5 分，15分で夫々 $73 \% ， 36 \%$ とGS 単独の添加の場合に比べ著るしく増加した。

脂肪組織の protein kinase と hCS との関係を Table 3 に示す. hCS を添加して incubation を行なう

Toble 3. Effect of hCS on protein kinase activity in rat epididymal fat pad in vitro.

\begin{tabular}{c|c|c}
\hline \hline \multirow{2}{*}{$\begin{array}{c}\text { Incubation } \\
\text { Time (min) }\end{array}$} & Protein Kinase Activity Ratio $(-\mathrm{cAMP} /+\mathrm{cAMP} \times 100)$ \\
\cline { 2 - 3 } & Control & hCS $100 \mu \mathrm{g} / \mathrm{ml}$ \\
\hline 0 & $42.8 \pm 2.2$ & $42.8 \pm 2.2$ \\
10 & $42.2 \pm 3.2$ & $50.4 \pm 4.4^{*}$ \\
20 & $36.9 \pm 7.0$ & $46.1 \pm 4.4^{* *}$ \\
\hline
\end{tabular}

The values are the mean \pm S.D. $(n=5)$

$* \mathrm{p}<0.01$ vs. the corresponding control

$* * \mathrm{p}<0.05$ vs. the corresponding control.

Table 4. Effect of hCS on FFA release in rat epididymal fat pad in vitro.

\begin{tabular}{c|c|c}
\hline \multirow{2}{*}{ Incubation Time (min) } & \multicolumn{2}{|c}{ FFA $\mu \mathrm{eq} / \mathrm{g}$} \\
\cline { 2 - 3 } & Control & hCS $100 \mu \mathrm{g} / \mathrm{ml}$ \\
\hline \hline 10 & 0 & $0.92 \pm 0.06^{*}$ \\
20 & $0.47 \pm 0.06$ & $1.66 \pm 0.47^{*}$ \\
\hline
\end{tabular}

The values are the mean \pm S.D. $(n=5)$

$*_{\mathrm{p}}<0.01$ vs. the corresponding control.

と, 開始後10分で対照に比較して明らかに脂肪組織 内 protein kinase の活性型の増加が認められた。 20分後でも, hCS を添加した脂肪組織中の protein kinase の活性型は同時間の対照に比し増加している が，10分間 incubation のそれと比べて少なかつた。

溶液中の FFA の測定成績を Table 4 亿示す. 溶液中の FFA は対照では incubation 10分後で検 出できず，20分後でで $0.47 \pm 0.01 \mu \mathrm{eq} / \mathrm{g}$ あつた。一 方, hCS を添加したものでは 10分後で $0.92 \pm 0.06$ $\mu \mathrm{eq} / \mathrm{g}, 20$ 分後で $1.66 \pm 0.47 \mu \mathrm{eq} / \mathrm{g}$ といずれも対照 に比して高い值を示した.

\section{2. in vivo 実験}

次に動物に hCS を投与して生体での脂質代謝に 対する hCS の影響を検討した，Fig. 5 はその実験 の結果を総括したものである。

副堹脂中 cyciic AMP 濃度は hCS 投与後 5 分で 増加しはじめ, 15分で最高となり, 以後急速に減少

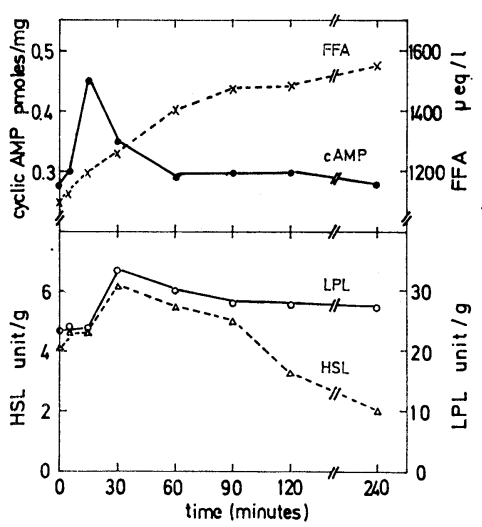

Fig. 5. Effect of hCS on cyclic AMP level, HSL and LPL in rat epididymal fat pad and on serum FFA level in vivo.

The values are the meanof 5 samples. 
して60分ではほぼ元の值にもどり，実験終了時の240分まで変動しなかつた。一方，対照として $0.1 \%$ BSA のみを投与した群では, 実験時間中副睪脂中の cyclic AMP 濃度に変動はみられなかつた。

副稙脂中のリポ蛋白リパーゼ（LPL）とホルモン感性リパーゼ（HSL）の活性は，hCS 投与後共に著明 に九進したが，二つのリパーゼの活性化と，その活性の持続には差が認められた。すなわち，HSL の活性 が hCS 投与後 5 分で亢進しはじめ，30分で最高となるのに対し，LPL の活性は前者と同様30分で最大と なるものの, 5 分, 15分では活性の充進は認められなかつた. 両りパーゼの活性は, hCS 投与後30分から 徐々に低下しはじめたが，90分を過ぎると HSL の活性のみが急速に低下し，240分では hCS 投与前の活 性の約 2 分の 1 となつた。一方，LPL の活性は90分以後もほとんど低下せず，240分後にもなお hCS 投与 前より高い值を保つていた。

血清中の FFA は hCS 投与後 5 分で増加しはじめ, 90分まで急速に増加した. 90分以後ではその増加の 速度は低下するものの，なお240分まで徐々に増加した。

\section{c. hCG の卵巣における protein kinase 活性化に対する作用の検討}

\section{1. 正常性周期ラット卵巣に対する作用}

Table 5 は, 正常性周期のうち, estrus と diestrus におけるラット卵巣を用いた実験の結果である. て れらの時期における in situ の卵单内 cyclic AMP 濃度は estrus で 2.2pmoles/mg, diestrus で 4.7pmoles /mg であつた。

Table 5. Gyclic AMP level and stimulation of protein kinase activity in normal cycling rat ovary by hGG.

\begin{tabular}{l|c|c|c}
\hline & $\begin{array}{c}\text { cAMP Level in Ovary } \\
\text { pmoles/mg }\end{array}$ & Protein Kinase Activity Ratio $(-$ cAMP/+cAMP $\times 100)$ \\
\cline { 2 - 3 } & $2.2 \pm 0.5$ & Control & hCG 100IU/ml \\
\hline Estrus & $4.7 \pm 1.0$ & 26.4 & 34.1 \\
Diestrus & 26.2 & 46.3 \\
\hline
\end{tabular}

The values of cyclic AMP are the mean \pm S.D. $(n=5)$.

The valnes of protein kinase are the mean of three experiments.

また, preincubation 終了時の活性型の protein kinase は, 対照の卵巣では両時期の卵宩共に protein

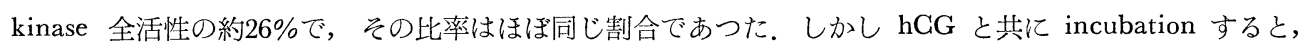
両時期の卵巣において共に明らかに protein kinose の活性型の比率が増加した. 特に diestrus においてそ の増加が著明であつた。

\section{2 . 妊娠各時期におけるラット卵巣に対する作用}

Table 6 は妊娠各時期におけるラット卵巣の protein kinase 活性におよぼす hGG の作用を検討した成 績である.

妊娠前期, 中期, 後期のいずれの時期の卵巣でも, hGG と incubation するととによつて, 卵巣内 protein kinase の活性型の比率が各々の対照に比べて著明に増加した.

Table 7 は妊娠初期 $\left(\mathrm{L}_{2}\right)$ の卵巣内 pratein kinase の活性化飞対する FSH, LH, hGG の作用を検討し た成績である。使用した濃度では FSH, LH, hGG いずれによつても卵巣内 protein kinase の活性型の比 率は対照に比べて増加した. FSH と LH の両者の成績を比較すると, その活性型の比率の増加は, LH投 与において FSH より大きい傾向が見られた。

\section{3. 未成熟ラット卵宩に対する作用}

生後14日，21日の未成熟ラット卵栄での成績を Table 8 亿示す.

生後21日の卵巣内 protein kinase 活性型の比率は使用した濃度の FSH, LH, hGG いずれによつても対 
Table 6. Stimulation of protein kinase activity in pregnant rat ovary by hGG.

\begin{tabular}{c|c|c}
\hline & \multicolumn{2}{|c}{ Protein Kinase Activity Ratio $(-\mathrm{cAMP} /+\mathrm{cAMP} \times 100)$} \\
\cline { 2 - 3 } & Control & hGG $100 \mathrm{IU} / \mathrm{ml}$ \\
\hline \hline $\mathrm{L}_{2}$ & 25.0 & 39.0 \\
$\mathrm{~L}_{5}$ & 30.8 & 43.6 \\
$\mathrm{~L}_{6}$ & 31.3 & 41.1 \\
$\mathrm{~L}_{11}$ & 25.0 & 44.0 \\
$\mathrm{~L}_{19}$ & 25.4 & 44.9 \\
\hline
\end{tabular}

The values are the mean of two experiments.

Table 7. Variation of protein kinase activation in pregnant rat ovary $\left(\mathrm{L}_{2}\right)$ by $\mathrm{FSH}, \mathrm{LH}$ and hCG.

\begin{tabular}{l|c|c|c|c|c|c}
\hline \multicolumn{6}{c}{ Protein Kinase Activity Ratio (-cAMP/+cAMP $\times 100)$} \\
\hline & \multicolumn{2}{|c|}{ FSH $20 \mu \mathrm{g} / \mathrm{ml}$} & \multicolumn{2}{|c|}{ LH $20 \mu \mathrm{g} / \mathrm{ml}$} & \multicolumn{2}{|c}{ hCG 100IU/ml } \\
\cline { 2 - 7 } & - & + & - & + & - & + \\
\hline \hline Exp. 1 & 27.8 & 31.5 & 25.2 & 45.5 & 25.0 & 39.0 \\
Exp. 2 & 27.3 & 30.7 & 28.5 & 37.2 & 26.5 & 48.2 \\
\hline
\end{tabular}

Table 8. Variation of protein kinase activation in immature rat ovary by $\mathrm{FSH}, \mathrm{LH}$ and hCG.

\begin{tabular}{|c|c|c|c|c|c|c|}
\hline \multicolumn{7}{|c|}{ Protein Kinase Activity Ratio $(-\mathrm{cAMP} /+\mathrm{cAMP} \times 100)$} \\
\hline \multirow{2}{*}{ Ages } & FSH & $20 \mu \mathrm{g} / \mathrm{ml}$ & LH & $20 \mu \mathrm{g} / \mathrm{ml}$ & hCG & $100 \mathrm{iu} / \mathrm{ml}$ \\
\hline & - & + & - & + & - & + \\
\hline 14 days & 42.5 & 38.7 & 35.7 & 47.8 & 46.1 & 52.8 \\
\hline 21 days & 47.0 & 61.0 & 49.0 & 66.3 & 55.7 & 65.8 \\
\hline
\end{tabular}

The values are the mean of two experiments.

照に比へて増加した。しかし生後14日の卵巣内 protein kinase 活性型の比率は, LH, hCG によつて増加 したが FSH によつて増加しなかつた。 また対照とした卵巣の preincubation 終了時の protein kinase 活 性型の比率は，生後14日，21日の卵策共に成熟ラット，弤娠ラットのそれに比べ高値であつた。

$$
\text { IV. 考按 }
$$

組織内 cyclic AMP 濃度の定量は, 最初 Rall ら ${ }^{24)}$ につて phosphorylase の活性化を利用して行なわ れ，ついで cyclic AMP を enzymatic 亿処理して radioactive 化する方法 ${ }^{25}$ などが開発されたが，いずれ も操作が複雑で高度の技術を要し，一般の研究室では実施するととが困難であつた。 1969年 Steiner ら ${ }^{26)}$ によつて発表された radioimmunoassay による定量法と，1970年に Walton ら ${ }^{23}$ およよ゙ Gilman ${ }^{15}$ によつ て相前後して発表された cyclic AMP binding protein を用いる定量法は，従来の方法に比へて簡便で， かつ多数の検体を処理できるととから，多くの研究室で採用され，賞用されている。乙のうち， Steiner ら の radioimmunoassay による方法で最も間題となる抗体の作成，ラベリングという点については，現在で 
は既に国内でも高価ではあるが assay一式が kit として市販され，解決された。一方，cyclic AMP binding protein を用いる方法は, binding protein が比較的たやすく精製でき，一度精製すると低温で数ケ月 間の保存が可能であるとと，廉価であるとと等の利点があり， binding assay に際し，組織からの cyclic AMP の抽出，精製という繁雑な操作が必要であるにもかかわらず，な捻れた cyclic AMP 測定法とい える。また, 測定感度の面から両者を比配しても, 文献的には実際上特に優劣はない. 以上のような得失を 考虑して，著者は cyclic AMP binding protein を用いる測定法を採用した。

さて， assay の基本となる binding protein を Gilman はウシ筋肉から，Walton らはウシ副腎から精 製しているが，著者はラット肝臓の cyclic AMP dependent protein kinase の分画を binding protein と して使用した. binding assay は acetate buffer を用いて行なつたが, ての buffer での pH optimum は pH 4.2 であつた。 また先述した検討成績に基いて, cyclic AMP の binding assay $の$ incubation $0^{\circ} \mathrm{C}$ で60分間行なつた。 assay medium に phosphodiesterase の阻害剤である theophylline を添加する必要は, この条件下ではないととが判明した， incubation 終了後，反応を止めるために $10 \mathrm{mM}$ Tris-Gl (pH 8.0)$40 \mathrm{mM} \mathrm{MgCl}{ }_{2}$ 溶液を加えると直ちに binding protein に結合した cyclic AMP が遊離しはじめるので, millipore filter で滤過するまでの時間を一定にする必要がある。 $0{ }^{\circ} \mathrm{C} て ゙$ incubation した場合に，60分前 後では, cyclic AMP の binding protein への結合はほとんどプラトーであり，反応を止めるために， buffer を加えた後の変化がより大であることを考慮しなくてはならない. 著者は 1 分おきに binding protein を加えて反応を開始し，60分後から 1 分おきに反応を停止してての問題に対処した。

standard curve から明らかなように, medium 中の cyclic AMP 濃度が大となると radioactivity のわ ずかの差が大きく濃度に反映してくるので，誤差を避けるために sample 量を適当に調整して適当な範囲 内で binding assay を行なう必要がある。同様に誤差を避ける目的で, カウンティングは10分間行ない, assay は全て duplicate assay とした.

とてろで, 組織から cyclic AMP を抽出する操作では, Dowex 50, H+ 型カラムクロマトグラフィーの 使用が有用であるが，組織量が不充分な場合にはむしろ TCA 処理のみを行ない， sample 数を多くして， バラツキを少なくする必要がある。従つて著者は cyclic AMP の抽出にあたつて，組織が比較的多く得ら れた副辠脂を用いる実験では，TCA 処理に加えて Dowex 50 カラムクロマトグラフィーを行ない，組織 量が不充分であつた卵巣を用いる実験では，TGA 処理のみを行なつた。

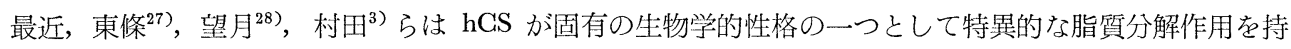
つととを報告した，とてろで脂肪組織中には脂質分解に関与するいくつかのリパーゼが存在するということ はすでによく知られている．特に脂肪細胞内で脂質分解に関与しているリパーゼの一つは HSL と呼ばれる triglyceride lipase であり，他は diglyceride lipase と monoglyceride lipase である. 後者二つはホルモ ン感受性ではなく，HSL よりはるかに活性が高い。しかし実際に脂質分解の律速段階に関与しているのは， HSL であると現在では考えられている。この HSL と cyclic AMP との関係は Rizack ${ }^{29) 30)}$ によてまず

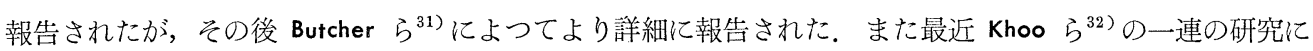
よつて，精製した HSL が protein kinase によつてリン酸化され，活性化されるととが明らかとなつた。 実際にホルモンによつて脂肪組織中に増加した cyclic AMP が組織内 protein kinase を活性化するかどう かという点を詳細に検討した Corbin $5^{16) 17)}$ の報告によると，組織内 cyclic AMP の濃度の上昇に伴なつ て, 組織内 cyclic AMP dependent protein kinase がたしかに活性化されるというととが確認されている. これらの報告から脂肪組織中 cyclic AMP 濃度の増加をもたらすホルモンは上記の機構を介して脂質分解 作用をもつと考えられる。そこで著者は hCS の脂質分解作用が adenyl cyclase-cyclic AMP 系を介して いるか不かを知るために，上記の点を検討した。

in vitro 実験での hCS による脂肪組織内 cyclic AMP 濃度の時間的変動は，著者らの行なつた同一条 件下での予備的実験の成績によると， epinephrine $(15 \mu \mathrm{g} / \mathrm{ml})$ 添加による脂肪組織内 cyclic AMP 濃度の 変化とほぼ一致したが，対照とした人成長ホルモン $(\mathrm{hGH}, 50 \mu \mathrm{g} / \mathrm{ml})$ では同一条件下で同一時間内には脂 
肪組織内 cyclic AMP 濃度の増減がみられなかつた。 また試験管内の実験でそれのみでは組織内 cyclic AMP 濃度に検出可能な変化を起さない量の caffeine $(1 \mathrm{mM})$ を hCS と共に添加すると, 脂肪組織中 cyclic AMP 濃度が hCS 単独添加の場合より著明に増加した。 この脂肪組織中 cyclic AMP 濃度の増加 は，わずか数10\%の order であるが，乙の程度の増加でも Sutherland ら ${ }^{33)}$ とると脂質分解の mediator として充分であるとされている。同様な試験管内の実験で, hCS は脂肪組織中 cyclic AMP dependent protein kinase を活性化するてとが確認されたし，FFA は hCS 添加後10分であきらかに増加した。つま $り$ in vitro 実験で hCS 添加によつて, 脂肪組織中 cyclir AMP 濃度がまず増加し, ほぼ同時に protein kinase の活性型の比率が増加しているとと, incubation 溶液中の FFA が徐々に増加するてとが明らかと なつた。一方，動物実験では hCS の投与によつてまずラット副宰脂中 cyclic AMP 濃度が増加しはじめ, 15分後に最高となり，ついで HSL の活性が方進しはじめ，30分後に最大の活性を示すようになる. 血清中 FFA は投与 5 分後から, HSL 活性が急速に低下する 90 分後まで急速に增加し, HSL の活性が低下すると 增加率が少なくなり, 以後実験終了時までほぼ一定の值を保つた。 以上の成績を綜合, 勘案すると, hCS は in vitro あるいは in vivo において adenyl cyclase-cyclic AMP 系を介して脂質分解作用をもつと思われ る.

Turtle $ら^{34)}$ は脂肪細胞浮遊液を用いた incubation 実験で，hCS の脂質分解作用を検討しているが，ての ホルモンを添加してから脂質分解作用がみられるまでに60分乃至90分の潜伏期間があるとと, との脂質分解 作用が actinomycin D p puromycin によつて阻害されることなどから， hCS によつて起る脂質分解作 用は hGH と同様に新しい蛋白合成を介して行なわれていると推論している。乙れは，著者らの実験成績 と矛盾しているが, hGS のもつ hGH 様作用, 免疫学的に hGH と部分交叉する事実などから, てのホル モンが cyclic AMP 系を介して脂質分解を行ないながら，一方では hGH と同様に新しい蛋白合成を介し て脂質分解を行なつている可能性も否定できない.

hCH の細胞内作用機序は各種の生理状態下におけるラット卵巣の protein kinase 活性化におよぼすそ の影響から検討した。

正常性周期をもつラット卵巣の estrus と diestrus の時期の卵巣内 cyclic AMP 濃度は夫々 2.2pmoles/ $\mathrm{mg}, 4.7 \mathrm{pmoles} / \mathrm{mg}$ であつて，性周期によつてその cyclic AMP の代謝が変動しているてとが判明した. またとれらの時期の卵巣を30分 preincubation したのちの protein kinase の活性型の比率がほぼ同一であ るにもかかわらず，同量の hCG と共に同一時間 incubation すると protein kinase の活性型の比率は後 者が前者より大となつた。 とのような成績は, diestrus の卵宩では hCG により sensitive な細胞か増加し ているととによると思われる.

妊娠各時期のラット卵巣では, 妊娠初期, 中期, 後期のいずれの時期においても hCG によつて protein kinase 活性型の比率がほぼ同程度に増加した。乙れは妊娠全期間を通じて，ラット卵巣では hGGに sensitive な細胞数に変化がないことを思わせるものである。また， $\mathrm{L}_{2}$ のラット卵巣を用いた実験では同じ蛋 白量の FSH による protein kinase の活性型の増加が LH のそれよりも小である傾向が見られた. しかし $\mathrm{L}_{2}$ の卵巣の FSH, LH, hGG に対する sensitivity の相違を明らかにするためには, FSH, LH, hCG の 夫々に対する dose-response 的な関係, および作用の時間的変動についてさらにくわしく検討する必要があ ると思われる。同様のととが，未成熟ラット卵巣のホルモン感受性についても言えるが，同一条件で preincubation した未成熟ラット卵巢中の protein kinase の活性型の比率が成熟ラット卵巢および妊娠ラット卵 巣のそれに比べて高いてとは興味ある成績であつて，未成熟ラット卵巣では protein kinase を介して行な われる代謝が元進していると思われる。

いずれにしても，てれらの実験条件下で，hGG はラット卵巣の protein kinase を活性化するてとが明 らかとなつた。 従つて, hGG のラット卵巣細胞内作用の発現は恐らく, adenyl cyclase-cyclic AMP 系を 介して行なわれるものと考えられるが, 卵巣自身の組織構築の相違によつて, その作用の発現が調節されて いる可能性がある. 


\section{V. 結 論}

以上の実験成績から次のような結論を得た。 ラット肝臓 cyclic AMP binding protein を用いて cyclic AMP binding assay を行なうために組織から cyclic AMP を抽出する時, 組織量が充分にあれば, TCA 処理に Dowex 50 カラムクロマトグラフィー処理を加えることが望ましい. 組織量が不充分の場合には TCA 処理のみで sample 数を增して測定值のバラッキを少なくさせる必要がある. cyclic AMP の binding assay には高比活性の $\mathrm{H}^{3}$-cyclic AMP を用い， $0{ }^{\circ} \mathrm{C}$ で60分間 incubation し，反応を停止してから millipore filter で滤過するまでの時間を一定とする必要がある.

hCS はラット副幸脂において, in vitro でも in vivoでも adenyl cyclase-cyclic AMP 系を介して脂 質分解作用を持つととが確かめられた。

hCG は in vitro の系で正常性周期ラット卵巣, 妊娠ラット各時期の卵巣, 未成熟ラット卵巣のいずれに おいても, cyclic AMP dependent protein kinase を活性化した.

本研究の一部は第46回, 47回日本内分泌学会学術集会に抢いて発表した.

謝辞 : 稿を終るに臨み, 御指導, 御校閲をいただいた恩師東條伸平教授ならびに西塚泰美教授に深謝いた します。また直接御指導, 御鞭撻をいただいた望月真人講師ならびに武田誠郎助教授に感謝いたします。さ らに足高善彦, 森川肇両助手を始めとする蛋白ホルモン研究グループの諸兄姉ならびに山村博平講師を始め とする本学第 2 生化学教室の諸兄姉の御援助, 御協力に感謝いたします。また種々の御援助をいただいた神 戸商船大学中田晃助教授に感謝いたします.

（本研究は文部省科学研究費の援助をうけた。）

\section{文献}

1) Sutherland, E.W. \& T.W. Rall : J. Biol. Chem., $232: 1077$, (1958). $\quad$ 2) Walsh, D.A., J.P. Perkins \& E.G. Krebs : J. Biol. Chem., $243: 3763$, (1968).

3）村田孝美：日本内分泌学会雑誌, $48: 6$, (1972).

4) Huttunen, J.K. \& D. Steinberg : Biochim. Biophys. Acta., 239 : 411, (1971). 5）東條伸平：第20回日本産科婦人科学会宿題報告，（1968）。 6) Ashitaka, Y., Y. Tokura, M. Tane, M. Mochizuki, and S. Tojo : Endocrinology, $87: 233$, (1970).

Swaminathan, N. and O.P. Bahl : Biochem. Biophys. Res. Commun. $40: 422$, (1970).

Bellisario, R., R.B. Carlsen, and O.P. Bahl : J. Biol. Ghem., 248 : 6769, (1973).

9) Carlsen, R.B., O.P. Bahl, and N. Swaminathan : J. Biol. Chem., 248 : 6810, (1973).

10) Morgan, F.J. and R.E. Ganfield : Endocrinology, 88 : 1045, (1971). 11$)$ Dorrington, J.H., and B. Baggett : Endocrinology, $84: 989$, (1969). 12) 森川 肇：日本内分泌学会雑誌, $49: 882,(1973)$. 13) Glynn, I.M. and J.B. Ghappel : Biochem. J. $90: 147,147$, (1964). 14) Yamamura, H., A. Kumon, K. Nishiyama, M. Tokeda, and Y. Nishizuka : Biochem. Biophys. Res. Commun., 45 : 1560, (1971). 15) Gilman, A.G. : Proc. Nat. Acad. Sci. U.S.A. : $67: 305$, (1970). 16) Gorbin, J.D., T.R. Soderling, and G.R. Park : J. Biol. Ghem., 248 : 1813, (1973). 17) Soderling, T.R., J.D. Corbin, and C.R. Pork : J. Biol. Chem., $248: 1822$, (1973). 18）久城英人，高野圭以，曾 山浩吉, 福井 嚴: 臨床病理, $18: 833$, (1970). 19) Dole, V.P. : J. Clin. Invest. $35: 150$, (1956). 20）松原嘉雄：日本内分泌学会雑誌，46：163，(1970). $21 ）$ 中田 晃：神戸大 学医学部紀要, $31: 106$, (1969). $\quad$ 22) Takeda, M. and Y. Ohga : J. Biochem., $73: 621$, (1973). 23) Walton, GM. and L.D. Garren : Biochemistry, 9 : 4223, (1970). 24) Rall, T.W., and E.W. Sutherland : J. Biol. Chem., 232 : 1065, (1958). $\quad$ 25) Breckenridge, B.. : Proc. Nat. Acad. Sci. U.S.A., 52 : 1580, (1964).

26) Steiner, A.L., D.M. Kipnis, R. Utiger, and G. Parker : Proc. 
Nat. Acad. Sci. U.S.A., 64 : 367, (1969).

27）東條伸平，望月真人，村田孝美，森川 肇，都倉康

正, 水沢富一, 椋田 亨: 臨床婦人科産科, $23: 1027$, (1969).

28）望月真人，村田孝美，森川

肇, 椋田 亨, 岡部桂一郎, 東條伸平：日本産科婦人科学会誌, $22: 610$, (1970).

29) Rizack,

M.A. : J. Biol. Chem., 236 : 657, (1961).

30) Rizack, M.A. : J. Biol. Chem., 239 : 392, (1964).

31) Butcher, R.W., R.J. Ho, H.C. Meng, and E.W. Sutherland : J. Biol. Chem., $240: 4515$, (1965).

32) Khoo, J.G., W.W. Fong and D. Steinberg : Biochem. Biophys. Res. Commun., 49 : 407, (1972).

33) Robinson, G.A., R.W. Butcher, and E.W. Sutherland : Cyclic AMP, 295, Academic press, New York. (1971).

34) Turtle, J.R and D.M. Kipnis : Biochim, Biophys. Acta. 144 : 583, (1967). 